\title{
Serum creatine kinase levels in normal females
}

\author{
R. K. SATAPATHY AND ROSALIND SKINNER \\ From the University Department of Human Genetics, Western General Hospital, Edinburgh
}

SUMMARY Serum creatine kinase levels were determined in 75 girls (age range, one month to 15 years) and 200 normal adult women (age range, 18 to 50 years). The values ranged from $12 \cdot 5$ to $80 \mathrm{IU} / 1$ in girls and 19 to $155 \mathrm{IU} / 1$ in adult females. The SCK level appeared to increase with age from 1 to 15 years, after which the level remained fairly constant. These data should be helpful in the detection of carriers of $\mathrm{X}$-linked forms of muscular dystrophy.

Determination of serum creatine kinase (SCK) levels has been accepted as the most reliable single test for detecting female carriers of X-linked Duchenne and Becker muscular dystrophies (Emery, 1969). One drawback to this method is that it yields about $25 \%$ false negatives (Walton and Gardner-Medwin, 1974). The carrier detection rate may be better in younger women, because in carriers the level of the enzyme decreases with increasing age (Dreyfus et al., 1970; Moser and Vogt, 1974; Skinner et al., 1975; Dubowitz, 1976; McCormick and Allen, 1976). Zellweger and Hanson (1970) reported that even in normal people the SCK level decreases with increasing age, but Griffiths (1964) and Wilson et al. (1965) did not find any significant age effect in normal controls. It has been suggested (Thompson et al., 1967; Moser and Vogt, 1974) that the number of false negative results could be minimised if carrier status were determined during childhood. It is therefore important to establish the range of SCK levels in normal females, both children and adults.

\section{Materials and methods}

Venous blood was collected from 75. girls aged between one month and 15 years. All these children were attending the Royal Hospital for Sick Children, Edinburgh, for treatment of disorders other than ones known to affect the SCK levels. None of the subjects had any family history of nervous or muscular disorders. Blood samples were also collected from 200 healthy females (age range, 18 to 50 years). Within 2 hours of collection of the blood the serum was removed and stored at $-20^{\circ} \mathrm{C}$. SCK levels were determined within 7 days by the method of Rosalki (1967). The assays were performed at $30^{\circ} \mathrm{C}$

Received for publication 20 July 1978 and the results expressed as International Units (IU) per litre.

All chemicals were supplied by Calbiochem Ltd.

\section{Results and discussion}

SCK levels in normal female children ranged between $12 \cdot 5$ to $80 \mathrm{IU} / 1$ with a mean of $39 \cdot 09 \pm 18 \cdot 12$. There was a small but non-significant tendency for SCK level to decrease in the first year of life, after which the level appeared to increase with age into adulthood. Though newborns have not been included in this series, Bodensteiner and Zellweger (1971) and Gilboa and Swanson (1976) reported very high levels of SCK during that period. According to Gilboa and Swanson (1976), the levels decreased to the normal range found in adults and older children 6 to 10 weeks after birth, whereas Zellweger and Hanson (1970) noted a gradual decline throughout the first year of life. The cause of high SCK level during the newborn period is not clearly understood. Bodensteiner and Zellweger (1971) attributed it to birth trauma, but Gilboa and Swanson (1976) have questioned this interpretation.

The present childhood results have been compared with SCK levels of 200 healthy adult females aged between 18 and 50 years previously estimated in this Department. When the individual results of the subjects between 1 and 50 years of age were plotted, and the best fit curve drawn through them, it appeared that the SCK level increased with age until about 15 years of age after which it seemed to remain fairly constant (Table 1, Fig.). The increase of SCK level with age could possibly be attributed to a positive correlation between SCK level and lean body mass, which was suggested by Hughes (1962), and later confirmed by Gracia (1974). Allen et al. (1960) showed that a crude but direct relationship exists 




Fig. SCK level vs. age. Best fitting line with $95 \%$ confidence limits.

between total body potassium and the fat free mass of growing females. They also showed an increase in potassium levels up to the age of 17 years, followed by an almost constant level up to 40 years of age. Later, Forbes and Hursh (1963), studying lean body mass in females from 7 to 32 years of age, showed an increase in lean body mass up to 15 years followed by an almost constant level thereafter.

Since the SCK level increases with age during childhood in normal females and decreases in carriers, it is likely that the difference in SCK levels in normal and carrier females would be greatest during the younger ages. The upper 95 th centile for female children from 1 to 15 years of age was 75 IU $/ 1$ and in the present series there was no case above $80 \mathrm{IU} / 1$ (Table 2).

Table 1 SCK values in different age groups in normal females

\begin{tabular}{lrlll}
\hline $\begin{array}{l}\text { Age range } \\
(y)\end{array}$ & $N o$. & \multicolumn{2}{l}{$S C K(I U / L)$} & \\
\cline { 3 - 5 } & & Mean & $S D$ & Range \\
\hline Less than 1 & 17 & $41 \cdot 14$ & $16 \cdot 99$ & $14 \cdot 0-72 \cdot 0$ \\
$1-2$ & 7 & $26 \cdot 28$ & $11 \cdot 52$ & $12 \cdot 5-43 \cdot 0$ \\
$3-4$ & 12 & $40 \cdot 91$ & $21 \cdot 76$ & $13 \cdot 0-70 \cdot 5$ \\
$5-6$ & 5 & $30 \cdot 50$ & $13 \cdot 72$ & $15 \cdot 5-51 \cdot 0$ \\
$7-8$ & 13 & $45 \cdot 69$ & $21 \cdot 60$ & $15 \cdot 0-75 \cdot 0$ \\
$9-10$ & 6 & $38 \cdot 00$ & $7 \cdot 75$ & $24-5-45 \cdot 5$ \\
$11-12$ & 7 & $42 \cdot 14$ & $23 \cdot 06$ & $20 \cdot 5-80 \cdot 0$ \\
$13-14$ & 4 & $37 \cdot 37$ & $17 \cdot 52$ & $18 \cdot 5-60 \cdot 5$ \\
$15-20$ & 68 & $46 \cdot 58$ & $17 \cdot 04$ & $21 \cdot 0-130 \cdot 0$ \\
$21-30$ & 75 & 47.97 & $20 \cdot 79$ & $19 \cdot 0-134 \cdot 0$ \\
$31-40$ & 38 & $45 \cdot 45$ & $16 \cdot 43$ & $27 \cdot 0-119 \cdot 0$ \\
$41-50$ & 23 & $50 \cdot 61$ & $29 \cdot 27$ & $21 \cdot 0-155 \cdot 0$ \\
\hline
\end{tabular}

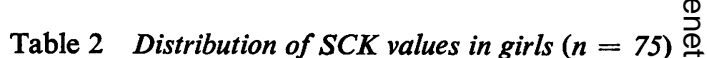
and women $(n=200)$

\begin{tabular}{|c|c|c|c|c|c|}
\hline \multirow{2}{*}{$\begin{array}{l}\text { Range of } \\
\text { SCK values } \\
(I U / l)\end{array}$} & \multicolumn{2}{|c|}{ Girls ( $<15$ years) } & \multicolumn{2}{|c|}{ Women $(>15$ years) } & \\
\hline & No. & $\%$ & No. & $\%$ & 므 \\
\hline $11-30$ & 27 & 36 & 26 & 13 & $\stackrel{0}{2}$ \\
\hline $31-50$ & 30 & 40 & 112 & 56 & $\bar{\tau}$ \\
\hline $51-70$ & 12 & 16 & 47 & $23 \cdot 5$ & c \\
\hline $71-90$ & 6 & 8 & 6 & 3 & עָׁ \\
\hline $91-110$ & 0 & 0 & 3 & $1 \cdot 5$ & \\
\hline $111-130$ & 0 & o & 4 & 2 & $\overrightarrow{0}$ \\
\hline $131-150$ & 0 & 0 & 1 & 0.5 & 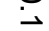 \\
\hline $151-170$ & 0 & 0 & 1 & 0.5 & $\vec{c}$ \\
\hline$>170$ & 0 & $\mathbf{0}$ & 0 & $\mathbf{0}$ & బ \\
\hline
\end{tabular}

Thus, the determination of carrier status shoufd preferably be carried out after infancy but certain $\vec{y}$ during childhood, since it would seem likely that during this period the test is most informative Ideally, in calculating the likelihood of hetere zygosity, the distribution of SCK levels in known carriers during childhood should also be taken in $\$$ account (Emery, 1976). However, even with pro\$ pective studies, this may be difficult to determire because until an accurate prenatal test for Duchente muscular dystrophy becomes available, potentiä carriers are unlikely to risk having any affected sons which might confirm their carrier status.

We are extremely grateful to Professor A. E. Emery for his help and advice with this project, an⿳亠口冋 to Dr J. D. Crombie of the Royal Hospital for Sich Children, Edinburgh, for providing the specimens $\&$ blood from the children in this study. We than Dr Susan Holloway for statistical advice.

This work was supported by a research grant fro $\overline{\mathrm{m}}$ the Muscular Dystrophy Group of Great Britain te. Professor A. E. H. Emery.

\section{References}

Allen, T. H., Anderson, E. C., and Langham, W. H. (1960). Total body potassium and gross body composition relation to age. Journal of Gerontology, 15, 348-357.

Bodensteiner, J. B., and Zellweger, H. (1971). Creatine phosphokinase in normal neonates and young infants Journal of Laboratory and Clinical Medicine, 77, 853-858

Dreyfus, J. C., Schapira, G., Schapira, F., and Démos, (1970). Nature of the carrier state in progressive musculat: dystrophy. In Muscle Diseases, pp. 417-423. Ed. by J. NO Walton, N. Canal, and G. Scarlato. Excerpta Medica, Amsterdam.

Dubowitz, V. (1976). Screening for Duchenne muscularo dystrophy. Archives of Disease in Childhood, 51, 249-25 1.

Emery, A. E. H. (1969). Genetic counselling in X-linke muscular dystrophy. Journal of the Neurological Scienceo 8, 579-587.

Emery, A. E. H. (1976). Methodology in Medical Genetics. A Introduction to Statistical Methods. Churchill-Livingstone, Edinburgh, London, and New York.

Forbes, G. B., and Hursh, J. B. (1963). Age and sex trends lean body mass calculated from $\mathrm{K}^{40}$ measurements; with a note on the theoretical basis for procedure. Annals of the New York Academy of Sciences, 110, 255-263. 
Gilboa, N., and Swanson, J. R. (1976). Serum creatine phosphokinase in normal newborns. Archives of Disease in Childhood, 51, 283-285.

Gracia, W. (1974). Elevated creatine phosphokinase levels associated with large muscle mass. Journal of the American Medical Association, 228, 1395-1396.

Griffiths, P. D. (1964). Serum levels of creatine phosphokinase. Journal of Clinical Pathology, 17, 56-57.

Hughes, B. P. (1962). A method for the estimation of serum creatine kinase and its use in comparing creatine kinase and aldolase activity in normal and pathological sera. Clinica Chimica Acta, 7, 597-603.

McCormick, D., and Allen, I. V. (1976). Serum creatine phosphokinase in the detection of carriers of Duchenne muscular dystrophy in Northern Ireland. Ulster Medical Journal, 45, (1), 79-83.

Moser, H., and Vogt, J. (1974). Follow-up study of serum creatine kinase in carriers of Duchenne muscular dystrophy. Lancet, 2, 661-662.

Rosalki, S. B. (1967). An improved procedure for serum creatine phosphokinase determination. Journal of Laboratory and Clinical Medicine, 69, 696-705.

Skinner, R., Emery, A. E. H., Anderson, A. J. B., and Foxall, C. (1975). The detection of carriers of benign
(Becker-type) X-linked muscular dystrophy. Journal of Medical Genetics, 12, 131-134.

Thompson, M. W., Murphy, E. G., and McAlpine, P. J. (1967). An assessment of the creatine kinase test in the detection of carriers of Duchenne muscular dystrophy. Journal of Pediatrics, 71, 82-93.

Walton, J. N., and Gardner-Medwin, D. (1974). Progressive muscular dystrophy and the myotonic disorders. In Disorders of Voluntary Muscle, 3rd ed., p. 561. Ed. by J. N. Walton. Churchill-Livingstone, Edinburgh, London. and New York.

Wilson, K. M., Evans, K. A., and Carter, C. O. (1965). Creatine kinase levels in women who carry genes for three types of muscular dystrophy. British Medical Journal, 1, 750-753.

Zellweger, H., Hanson, J. W., and Markowitz, E. (1970). Age- and sex-dependent differences of serum enzymes in normal controls. In Muscle Diseases, pp. 445-449. Ed. by J. N. Walton, N. Canal, and G. Scarlato. Excerpta Medica, Amsterdam.

Requests for reprints to Dr R. K. Satapathy, Department of Human Genetics, Western General Hospital, Edinburgh EH4 2XU. 